\title{
Densities and Zonation Patterns of Native and Non-Indigenous Oysters in Southern California Bays
}

\author{
Nicole B. Tronske ${ }^{1} \cdot$ Thomas A. Parker $^{2} \cdot$ Holly D. Henderson ${ }^{3} \cdot$ Jennifer L. Burnaford ${ }^{2} \cdot$ Danielle C. Zacherl $^{2}$ (D)
}

Received: 2 November 2017 / Accepted: 20 June 2018 / Published online: 10 July 2018

(C) The Author(s) 2018

\begin{abstract}
Worldwide, artificially armored shorelines can dominate available estuarine habitat. Increases in artificial substrata in southern California, USA, coincide with increased abundances of nonindigenous species. The US west coast Olympia oyster, Ostrea lurida, may be particularly sensitive to changes in natural habitat availability and recently experienced large-scale declines in abundance. Simultaneously, the non-indigenous and often invasive Pacific oyster, Crassostrea gigas, has been introduced along the US West Coast, including into southern California estuaries where its impact is unstudied. We recorded C. gigas and $O$. lurida densities from October 2010 through July 2017 throughout southern California on several habitat types and as a function of tidal elevation as a critical baseline for evaluating impacts of $C$. gigas. Ostrea lurida was present in higher proportions than $C$. gigas in hard substrate-dominated habitats, whether natural or human-introduced. A strong zonation pattern emerged; $C$. gigas achieved its maximum density above $+0.4 \mathrm{~m}$ MLLW versus $O$. lurida at or below $+0.2 \mathrm{~m}$ MLLW. These data reveal the optimal tidal elevation for placement of a restored $O$. lurida bed and establish a critical baseline and techniques for evaluating future changes in oyster density.
\end{abstract}

Keywords Ostrea lurida $\cdot$ Crassostrea gigas $\cdot$ Pacific oyster $\cdot$ NIS $\cdot$ Exotic species $\cdot$ Zonation

\section{Introduction}

Across the globe, humans have extensively reworked estuaries and bays to develop shoreline property and protect against shoreline erosion. This reworking includes extensive shoreline armoring via construction of riprap breakwaters and seawalls, particularly in highly urbanized areas. In San Diego Bay, California, USA, 74\% of the shoreline is armored with riprap, seawalls, and other artificial structures (Tierra Data Inc. 2013). These human-introduced substrata can change

Nicole B. Tronske and Thomas A. Parker contributed equivalent effort to this work.

Danielle C. Zacherl

dzacherl@fullerton.edu

1 Department of Biological Sciences, California State Polytechnic University Pomona, 3801 W. Temple Avenue, Pomona, CA 91768, USA

2 Department of Biological Science (MH-282), California State University, Fullerton, 800 North State CollegeBlvd., Fullerton, CA 92831-3599, USA

3 Merkel \& Associates, Inc., 5434 Ruffin Road, San Diego, CA 92123 , USA community structure (Connell 2001; Bulleri and Chapman 2004; Tyrrell and Byers 2007), support lower diversity (Moschella et al. 2005; Pister 2009), and may facilitate the spread of nonindigenous species (NIS) (Bulleri and Airoldi 2005; Tyrrell and Byers 2007, but see Pister 2009 for a review of studies finding little to no effect). Placement of human-introduced substrata, combined with other activities such as infilling, dredging, and channelization, has led to significant declines of naturally occurring habitat.

One severe example of natural habitat reduction has been an $85 \%$ global decline in oyster reef habitat (Beck et al. 2011). Oyster reefs once dominated the habitat in coastal estuaries and delivered important ecosystem services via their ability to provide refugia for communities of organisms (Grabowski et al. 2005), improve water clarity (Grizzle et al. 2008), stabilize sediments (Meyer et al. 1997; Piazza et al. 2005), and provide food for important fisheries (Bonnot 1935; MacKenzie Jr and Wakida-Kusunoki 1997; Cranfield et al. 1999). The loss of vast amounts of habitat had devastating effects on the value of the global oyster fishery (Guo et al. 1999) and on ecosystem services provided by oysters, therefore, efforts to restore this once ubiquitous habitat are underway.

On the U.S. west coast, the oyster habitat destroyed was that of the Olympia oyster, Ostrea lurida Carpenter, 1864. 
This species, currently distributed from British Columbia, Canada (Polson and Zacherl 2009) to Guerrero Negro, Baja California, Mexico (Raith et al. 2015), suffered declines of $>90 \%$ of its beds in Washington, USA and $>99 \%$ loss along the rest of its range (Beck et al. 2011) due to anthropogenic impacts including overharvesting and pollution (Hopkins 1931; Bonnot 1935; reviewed in Baker 1995). Currently, in southern California, the species exists as remnant individuals on natural and human-introduced substrata in bays and harbors (Polson and Zacherl 2009). There is significant interest in re-establishing oyster bed habitat across this species' range (Dinnel et al. 2009; McGraw 2009; White et al. 2009b) to return ecosystem services and harness the ability of oyster bed habitat to act as a living shoreline (Megan Cooper, personal communication, California State Coastal Conservancy, May 2015). Small-scale restoration studies demonstrate the efficacy of doing so (Zacherl et al. 2015).

Associated with the extensive reworking of wetlands, bays, and estuaries has been the continued rise in non-indigenous species (NIS) introductions (Ruiz et al. 2000; Bulleri and Airoldi 2005). San Francisco Bay is thought to be the most heavily invaded bay on the US west coast (Ruiz et al. 2000) with 175 NIS in 2011 (Cohen 2011); southern California bays and estuaries also contain a large number of NIS, with up to 106 documented species (Cohen 2011). These NIS are sometimes numerically dominant; in southern California, Cohen et al. (2005) observed very high proportions of NIS on humanintroduced habitats such as floats $(43 \%)$ and subtidal fixed structures $(64 \%)$. While many of these introductions may ultimately fail, the specter of successful pest species introduction keeps conservationists on high alert because of the potential negative impact on native species assemblages (Lodge et al. 2006, and references therein). For example, the pest NIS, Caulerpa taxifolia, has remarkable potential to exact devastation on local species (Boudouresque et al. 1995; Balata et al. 2004). It invaded two southern California estuaries, necessitating expenditure of millions of dollars over a decade to eradicate it (Withgott 2002; Anderson 2005).

Crooks et al. (2015) recently detected another potential pest NIS, the Pacific oyster, Crassostrea gigas, in several southern California bays and estuaries. This NIS from Japan is the most common oyster in aquaculture and the most geographically widespread oyster species in the world, established on every continent except Antarctica (Shatkin et al. 1997; Ruesink et al. 2005). Initial C. gigas introduction to California has been attributed to deliberate planting in 1929 into central California at Tomales Bay and Elkhorn Slough (Conte 1996). In southern California, C. gigas has also been deliberately planted into Newport Bay, San Diego Bay, and Catalina Island from 1930 to 1960 (Barrett 1963; Carlton 1979, and reviewed in Crooks et al. 2015). Further, Smith et al. (1987) and Stephenson et al. (1986) out-planted juveniles into Marina Del Rey, Newport Bay, and San Diego Bay to monitor tributyltin effects. Farming of $C$. gigas has taken place in Baja California, Mexico since the 1970s (Islas-Olivares 1975) and in southern California since the 1980s (in Santa Barbara and Carlsbad). Despite these numerous intentional introductions, $C$. gigas was not detected outside of aquaculture settings anywhere south of Morro Bay in a 1991 west coast estuaries survey (Emmett et al. 1991). The species was noted in Los Angeles Harbor in a non-indigenous rapid assessment survey in 2000 (Cohen et al. 2005), but the earliest documented consistent and wide-spread observations of the species throughout southern California occurred in 2005 (Crooks et al. 2015; Polson and Zacherl 2009).

There is some evidence that $C$. gigas can negatively impact $O$. lurida. Buhle and Ruesink (2009) found O. lurida growth rate and survival declined with increasing density of $C$. gigas in Willapa Bay, WA. Trimble et al. (2009) suggested that $C$. gigas shell at upper tidal elevations may serve as a recruitment sink for $O$. lurida in WA, where it is otherwise limited to the lower intertidal to shallow subtidal due to freezing and desiccation stress. Globally, the influence of $C$. gigas on other oyster species and its new community varies from invasive threat (NSW Department of Primary Industries 2012), to significant habitat transformer via increases in structural complexity (reviewed in Troost 2010), to facilitator of increased community diversity (e.g., Trianni 1996) and local species density (Dumbauld et al. 2001; Hosack et al. 2006), to having no detectable impact (e.g. on infauna, Dumbauld et al. 2001) or equivocal impact (Troost 2010). Sometimes the lack of impact on native bivalves is because non-indigenous oysters do not overlap in habitat with their native counterparts. When habitat overlap occurs, NIS typically outgrow native species (Ruesink et al. 2005). In Australia and New Zealand, areas of overlap are dominated by $C$. gigas which overgrow and smother the native Sydney rock oyster, Saccostrea glomerata, but the native oyster can survive emersion longer and therefore persists at higher tidal elevations (Krassoi et al. 2008). In British Columbia, C. gigas is found in the barnacle zone above $+1.3 \mathrm{~m}$ MLLW where it does not appear to exclude native species and may facilitate barnacle settlement (Bourne and Mann 1979). Because C. gigas' impact varies across the globe, it is difficult to predict the potential for $C$. gigas in southern California to impact local communities or outgrow and displace $O$. lurida, though studies from Washington (Buhle and Ruesink 2009; Trimble et al. 2009) suggest that O. lurida may be at risk.

Because $C$. gigas is a successful colonizer throughout the world, and at times an invasive pest that impacts native oyster species, it is important to document its current population status. Establishing a baseline is important not only to analyze the effects of invasive threats, but also to examine shifts in species and their habitats due to climate change (Sagarin et al. 1999), to assess and implement conservation measures (Lotze and Worm 2009), and to evaluate the effects of pollution or 
other anthropogenic impacts. The Pacific oyster has become increasingly detectable in southern California in the past decade, although it is not yet clear whether its presence is ephemeral or the start of established self-sustaining populations. Knowledge of its current population status is critical in southern California, where intense development has left little natural habitat remaining, and the preponderance of artificial substrata dominate and may facilitate proportionally higher recruitment of NIS. Thus, an important preliminary step in understanding the potential impact of $C$. gigas on southern California estuaries, and on $O$. lurida, is to establish baseline demographic data for both species. With this goal, we measured the densities of both oyster species across multiple sites, habitat types, and tidal elevations, in several southern California bays.

\section{Methods}

From 2010 to 2013, we surveyed Ostrea lurida and Crassostrea gigas densities and substratum availability at multiple sites in Newport Bay, Alamitos Bay, Huntington Harbour, Los Angeles Harbor, and San Diego Bay, California, USA (Fig. 1). Sites were selected haphazardly based upon ease of access, though when possible, we sampled across a variety of habitats, including cobble fields, mud and sand habitats, seawalls, riprap, and pilings. All sites were located in areas of each bay with salinity and temperature conditions known to support both species.

\section{Density and Substratum Availability Surveys}

Within each site, we surveyed during low tides of $-0.15 \mathrm{~m}$ mean lower low water (MLLW) or lower. In general, in southern California, tides can range between $\sim-0.4 \mathrm{~m}$ and $+2.0 \mathrm{~m}$ each month, so constraining our surveys to days achieving $-0.15 \mathrm{~m}$ allowed us to generally maximize the tidal range surveyed. We sampled a band 2 to $4 \mathrm{~m}$ in width (depending upon slope), in an attempt to capture the majority of the oyster zone. However, because we sampled different habitat types with vastly differing slopes, this meant that sometimes we sampled across a much broader tidal range than in other instances (e.g. seawall vs. soft habitat).

On soft, cobble, riprap, and wall habitats, we surveyed replicate randomly placed $0.5-\mathrm{m}$ length $\times 0.5-\mathrm{m}$ height $\left(0.25 \mathrm{~m}^{2}\right)$ quadrats $(n=13-31)$ along a $50-\mathrm{m}$ transect placed in the middle of the visible oyster zone. All oysters that fell at least halfway within each quadrat were enumerated and identified. Identification of each oyster was via shell length, presence or absence of external foliations on the shell, shell fouling, and, as necessary, examination of internal shell color and presence or absence of chomata (as in Polson et al. 2009; Raith 2013). On piling habitat, we surveyed one $0.25 \mathrm{~m}^{2}$ quadrat per piling for all pilings available up to a distance of $50 \mathrm{~m}$ along the shore using flexible quadrats that wrapped around the structure. For each piling and on seawall habitat, we determined the surveyable range from the bottom of the piling to the highest visible oyster, randomly placing piling quadrats with respect to height and face, and wall quadrats with respect to height.

After counting oysters in our quadrats, we placed a gridded $0.25 \mathrm{~m}^{2}$ quadrat in the same location to determine substratum availability using a point-contact technique with 49 points per quadrat. At each point we identified the substratum first encountered under a probe tip. For mobile organisms, we counted the substratum beneath. For algae and eelgrass, we scored that substratum if the probe hit the point of attachment; otherwise we counted the substratum underneath. Substratum categories included mud, sand, gravel, small rock, medium rock, large rock, boulder, seawall, piling, concrete, wood, dead shell, mussel, live $O$. lurida, live $C$. gigas, clam, scallop, barnacle, rope, PVC pipe, unspecified plastic, metal pipe, tunicate, Serpulorbis squamigerus, tire, brick, sponge, sandcastle worm, bryozoan, Ulva sp., and eelgrass. We then collapsed a subset of the substrata (all except mud, sand, tunicate, sponge, Ulva sp., and eelgrass) into one category called "hard substrata".

At the upper and lower extremes of the band transect we estimated tidal elevation using a LaserMark LM-30 rotary laser. Using the laser, we calculated the difference in height from the water's edge at a specified time and the upper and lower corners of our band transect, and added the difference to predicted tidal elevations (accessible at http://tbone.biol.sc. edu/tide or https://tidesandcurrents.noaa.gov/tide predictions.html) from the nearest NOAA station relative to each survey site (see Table 1 for stations used to generate tidal predictions for each site). These estimates did not account for barometric pressure or tidal surge and thus represent an estimate of tidal elevation.

Due to the limited replication within each habitat type (i.e., seawall vs. cobble vs. pile, etc.), we took a descriptive, rather than inferential, statistical approach to provide baseline information for oyster densities and substratum availability in southern California. Within each site, we calculated mean density ( \pm 1 SE) per habitat type. For among-habitat and among-bay comparisons we calculated grand weighted means ( $\pm 1 \mathrm{SE}$ ). We also calculated grand weighted means of the proportion of $C$. gigas to total oysters to allow comparisons among habitat types and bays.

\section{Distribution Across Tidal Range}

Based upon the primary literature (Krassoi et al. 2008) and qualitative observations of possible zonation between the oyster species, we conducted additional surveys in 2013 and 2014 

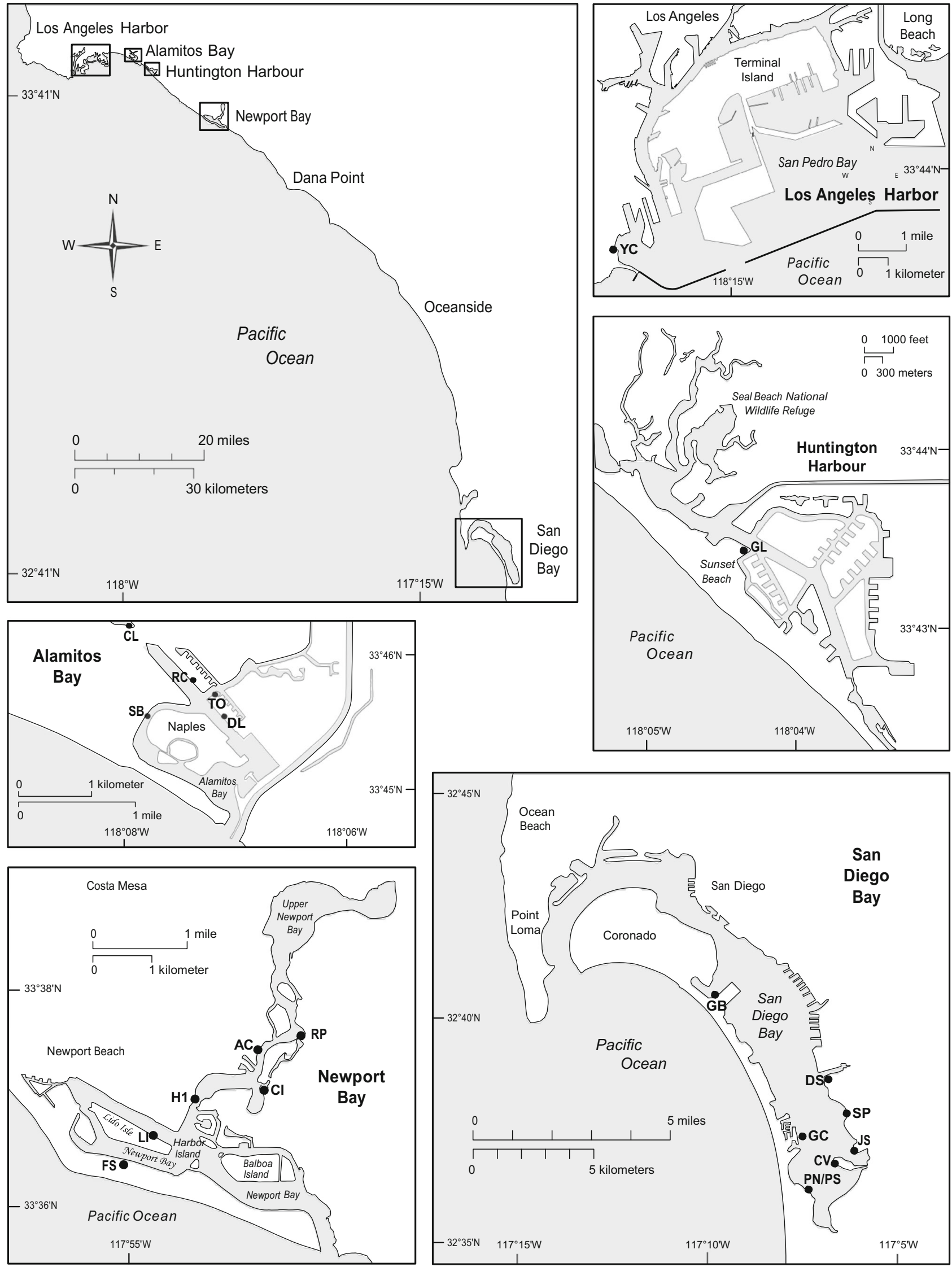

Fig. 1 Site map for locations in southern California, U.S.A., surveyed between October 2010 and July 2017. Site names are coded as in Tables 1 and 2 


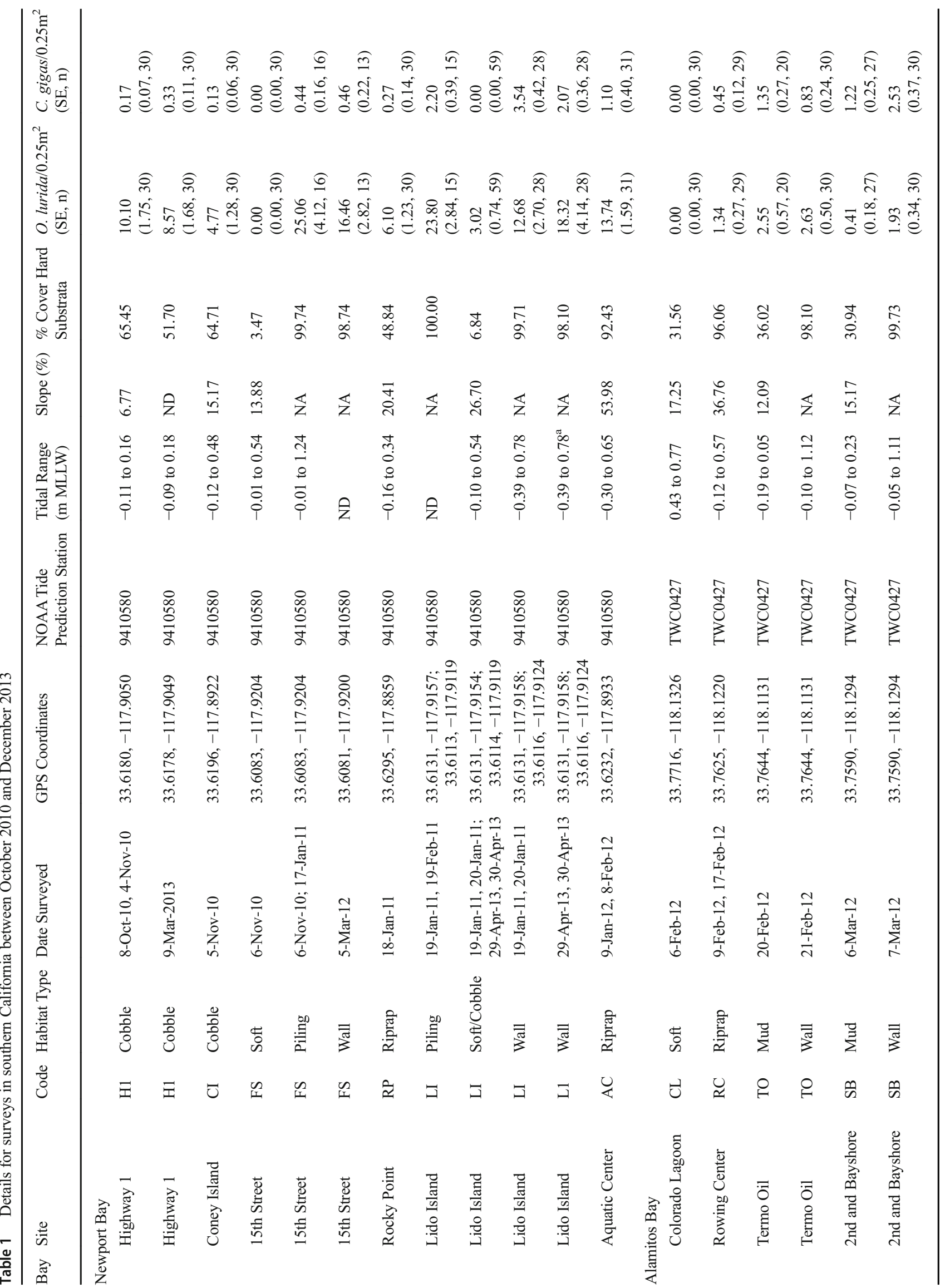




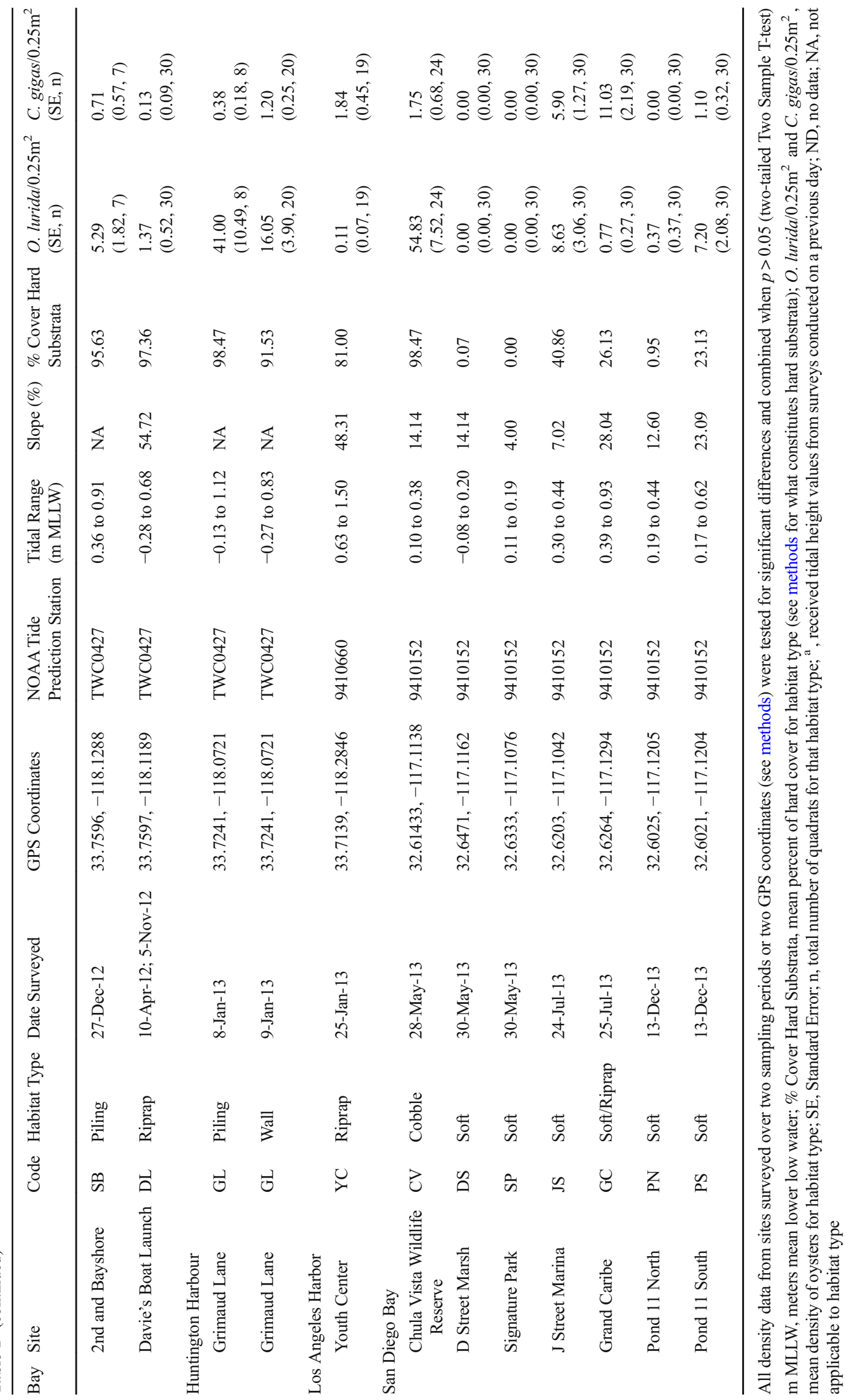


to quantify densities of both species as a function of tidal elevation at three different sites including seawalls in Alamitos Bay and Huntington Harbour, and a chain-linked fence extending into the water in Glorietta Bay (within San Diego Bay). We chose vertical substrata because of the ability to measure densities of both species across a large tidal range.

At each site, we measured twenty meters of continuous wall or fence. Each meter along the transect contained one quadrat that measured $0.3 \mathrm{~m}^{2}(1.0$-m length $\times 0.3$-m height $)$ and was assigned a random tidal elevation between the bottom of the wall and the top of the barnacle zone by placing a meter stick against the surface and assigning a random number (in $\mathrm{cm}$ ) to identify where the lowest corner of the quadrat should be placed. All oysters that fell at least halfway within the quadrat were enumerated. Tidal elevation was estimated for each quadrat using a LaserMark LM-30 rotary laser as specified above.

In 2017, we returned to Glorietta Bay to characterize tidal zonation of oysters using more precise and accurate measures of tidal elevation, while also broadening the tidal elevations surveyed including above the barnacle zone. We employed a Leica Geosystems system 1200 real-time kinematic global positioning systems (RTK-GPS) unit receiving position corrections via Leica's SmartNet base station network to record position $(\mathrm{x}, \mathrm{y})$ and elevation $(\mathrm{z})$ in real time. Additionally, we sampled zonation on a cobble field within Chula Vista Wildlife Reserve (CVWR). At Glorietta Bay, we used methods comparable to those used in 2014. At CVWR, we laid out five $30 \times 1-\mathrm{m}$ transects parallel to the water line across tidal elevations ranging from approximately $-0.5 \mathrm{ft}$. MLLW to +4 ft. MLLW. On each transect we randomly generated X values along the transect and alternately placed a total of 7 10 quadrats above or below the transect line for a total of 45 quadrats. For each quadrat, we recorded the number of each oyster species and calculated density $/ 0.25 \mathrm{~m}^{2}$. At each quadrat at each site, we placed the RTK-GPS pole into the approximate center of the quadrat and recorded the tidal elevation in $\mathrm{ft}$. NAVD. Upon completion of field work, survey data were reviewed for quality and we converted elevation from $\mathrm{ft}$. NAVD to ft. MLLW using a conversion of 0.43 (from NOAA Tides and Currents San Diego Station). The horizontal datum was NAD83 CAZ6, feet (epoch 2010) and the vertical datum was NAVD88, ft. (Geoid 12a).

We transformed raw counts of oysters in $0.3 \mathrm{~m}^{2}$ quadrats into density $/ 0.25 \mathrm{~m}^{2}$ and $\mathrm{ft}$. MLLW to $\mathrm{m}$ MLLW to facilitate comparison with other density data collected. To evaluate the relationship between tidal elevation and oyster density, for each species at each site, we fitted either a linear regression line or a polynomial line (degrees $=2$ ), as appropriate, and used ANOVA to test for goodness of fit using JMP 12.0 or JMP 13.0 statistical software.

Data Availability The datasets analyzed during the current study are available from the corresponding author on request.

\section{Results}

\section{Density and Substratum Availability Surveys}

We completed density and substratum availability surveys at 20 sites across 5 bays; at 5 sites, multiple habitat types were surveyed on separate transects, and at 2 sites, we repeated surveys in a subsequent year, for a total of 33 transects surveyed (Table 1). Percent cover of hard substrata varied substantially within and among habitat types, ranging from 0 to $40 \%$ in mud habitat, $49-97 \%$ in riprap, $52-98 \%$ in cobble, $92-99 \%$ on wall, and $96-100 \%$ on piling (Table 1). Note that since cover was recorded as the substrate first encountered with the probe, it was sometimes possible to have $<50 \%$ cover in hard habitat types, if, for example, mud was present and deposited upon riprap. There were four transects where we did not detect any living oysters of either species within the quadrats; all of these survey locations were in mud or mud/sand habitats (Table 1) with low \% cover hard substrata $(0-3.5 \%)$ except Colorado Lagoon, Alamitos Bay, with $31.6 \%$ cover of hard substrata. Qualitatively, both species were present at these sites but not detected by surveys (i.e., on other habitat types, see Table 1, or on scattered refuse, e.g., tires, present at the site but not within transects). Of 29 transects where we did detect and record living oysters, Ostrea lurida was present at higher densities than Crassostrea gigas on all but 5 transects (Table 1). Qualitatively, we generally observed multiple size classes of both species at the majority of sites surveyed.

Across all bays, sites, and habitat types, $O$. lurida densities ranged from 0.00 oysters $/ 0.25 \mathrm{~m}^{2}$ at several locations to 54.83 \pm 7.52 (SE) oysters $/ 0.25 \mathrm{~m}^{2}$ at CV, in San Diego Bay (Table 1). O. lurida density varied greatly among habitat types within bays and between bays. In general, there were higher $O$. lurida densities across all habitat types in Newport Bay compared to Alamitos Bay (Fig. 2). In Newport Bay, where we surveyed the broadest selection of habitat, $O$. lurida density was higher on human-introduced (riprap, walls, and pilings) versus natural habitats (soft and cobble). This same general trend among habitat types was observed in Alamitos Bay (Fig. 2). In San Diego Bay, the highest density was at $\mathrm{CV}$, where the habitat was composed of cobble and small rocks (natural habitat). The density of $O$. lurida on cobble at CV (with $98 \%$ hard substratum) was over 7-times higher than on cobble in Newport Bay (with $52-65 \%$ hard substratum available).

Across all bays, sites, and habitat types, $C$. gigas densities ranged from $0.13 \pm 0.09$ (SE) oysters/ $0.25 \mathrm{~m}^{2}$ at $\mathrm{DL}$ in Alamitos Bay (Table 1) to $21.90 \pm 4.40$ (SE) oysters $/ 0.25 \mathrm{~m}^{2}$ at GB, in San Diego Bay (Table 2). When considering densities across habitat types within bays, with the exception of GC in San Diego, densities did not appreciably differ among habitat types (Fig. 3), except that seawalls may support slightly higher densities than other habitat types. There was no clear 


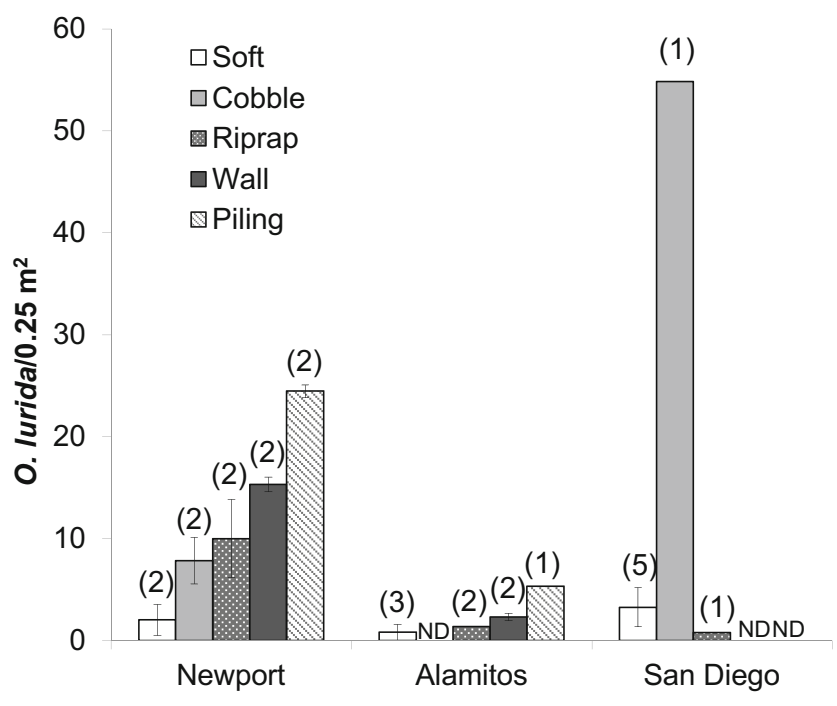

Fig. 2 Ostrea lurida densities (grand weighted mean \# oysters $/ 0.25 \mathrm{~m}^{2}$ ) on various substrata in Newport, Alamitos, and San Diego Bays from surveys conducted between 2010 and 2013. Bars represent \pm 1 SE. Numbers in parentheses above each bar indicate number of sites contributed to calculating the grand weighted mean and SE; within site means were calculated using $n=7-31$ quadrats (Table 1 ), quadrats were nested within sites. ND $=$ No Data

pattern of densities across habitat types between bays when comparing Newport Bay to Alamitos Bay, but we recorded exceptionally high densities of $C$. gigas at two locations in San Diego Bay - on the chain link fence at GB (Table 2) and on riprap at GC (this survey also was at a notably higher tidal elevation than the others, Table 1).

To address whether human-introduced habitats may influence NIS distributions, we examined proportions of the NIS C. gigas to total oysters within each bay on each habitat type. Soft-sediment habitats (natural) in 1 of 2 bays contained higher proportions of $C$. gigas than $O$. lurida, while cobble habitats (natural) in 2 of 2 bays contained higher proportions of $O$. lurida (Fig. 4). For humanintroduced habitats, riprap contained higher proportions of $O$. lurida in 2 of 3 bays, and wall and piling habitats were each dominated by $O$. lurida in 2 of 2 bays.

\section{Distribution Across Tidal Range}

Ostrea lurida densities varied linearly and significantly as an inverse function of tidal elevation across all but one site surveyed, reaching maximum density at $0.2 \mathrm{~m}$ MLLW or lower, while $C$. gigas densities increased with tidal elevation, achieving maximum density at $0.4 \mathrm{~m}$ MLLW and higher (Fig. 5). $O$. lurida consistently occurred within and underneath the welldefined mussel zone (dominated by Mytilus galloprovincialis) while $C$. gigas consistently occurred within and above the mussels, approaching the top of the barnacle zone. C. gigas density varied linearly with elevation at the sites where our surveys occurred in a limited range of tidal elevations (Fig. 5a-

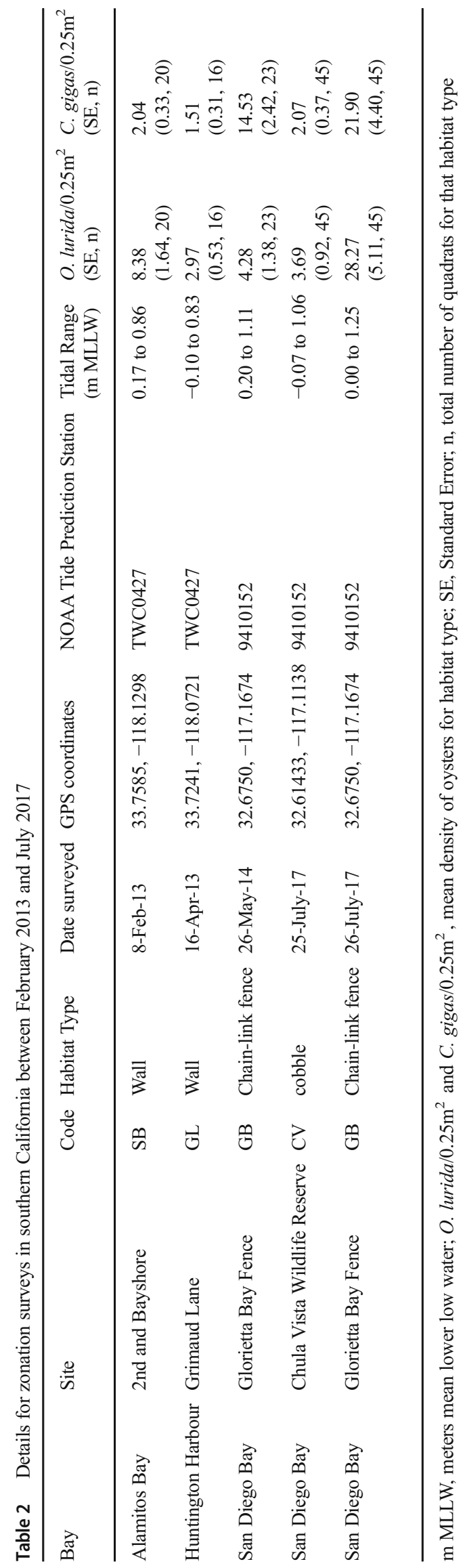




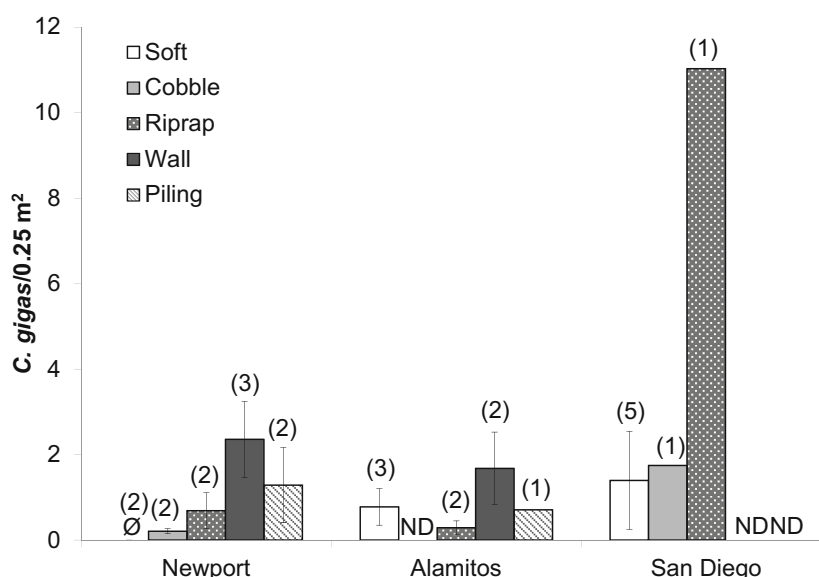

Fig. 3 Crassostrea gigas densities (grand weighted mean \# oysters/ $0.25 \mathrm{~m}^{2}$ ) on various substrata in Newport, Alamitos, and San Diego Bays from surveys conducted between 2010 and 2013. Bars represent \pm 1 SE. Numbers in parentheses above each bar indicate number of sites contributed to calculating the grand weighted mean and SE; within site means were calculated using $n=7-31$ quadrats (Table 1 ), quadrats were nested within sites. ND $=$ No Data

b); at those sites where we surveyed a broader elevation range including the uppermost reaches of the intertidal zone, the relationship was best described by a polynomial function (Fig. 5c-e). The linear relationship with tidal elevation was significant for both species at SB in Alamitos Bay $(O$. lurida: $\mathrm{F}(1,18)=6.92, P=0.017, C$. gigas: $\mathrm{F}(1,18)=9.22, P=$ 0.0071 ), for $C$. gigas at GL in Huntington Harbour (F $(1,13)=10.18, P=0.0071)$ and $O$. lurida at GB in San Diego Bay in $2014(\mathrm{~F}(1,21)=20.15, P=0.0002)$ and 2017 $(\mathrm{F}(1,43)=33.39, P<0.001)$, and $\mathrm{CV}$ in $2017(\mathrm{~F}(1,43)=$ 26.43, $P<0.001)$. While not significant, the trend was still evident for $O$. lurida at GL in Huntington Harbour (F $(1,14)=2.22, P=0.1582$, Fig. 5a). We surveyed a broader

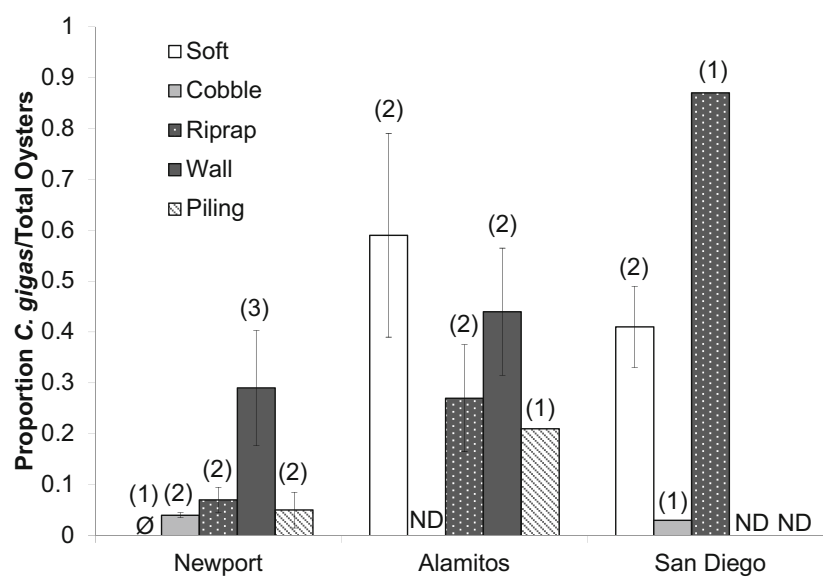

Fig. 4 Crassostrea gigas proportions (\# C. gigas/total \# oysters) on various substrata in Newport, Alamitos, and San Diego Bays from surveys conducted between 2010 and 2013. Bars represent \pm 1 SE. Numbers in parentheses above each bar indicate number of sites contributed to calculating the grand weighted mean and SE; within site means were calculated using $n=7-31$ quadrats (Table 1 ), quadrats were nested within sites. ND $=$ No Data
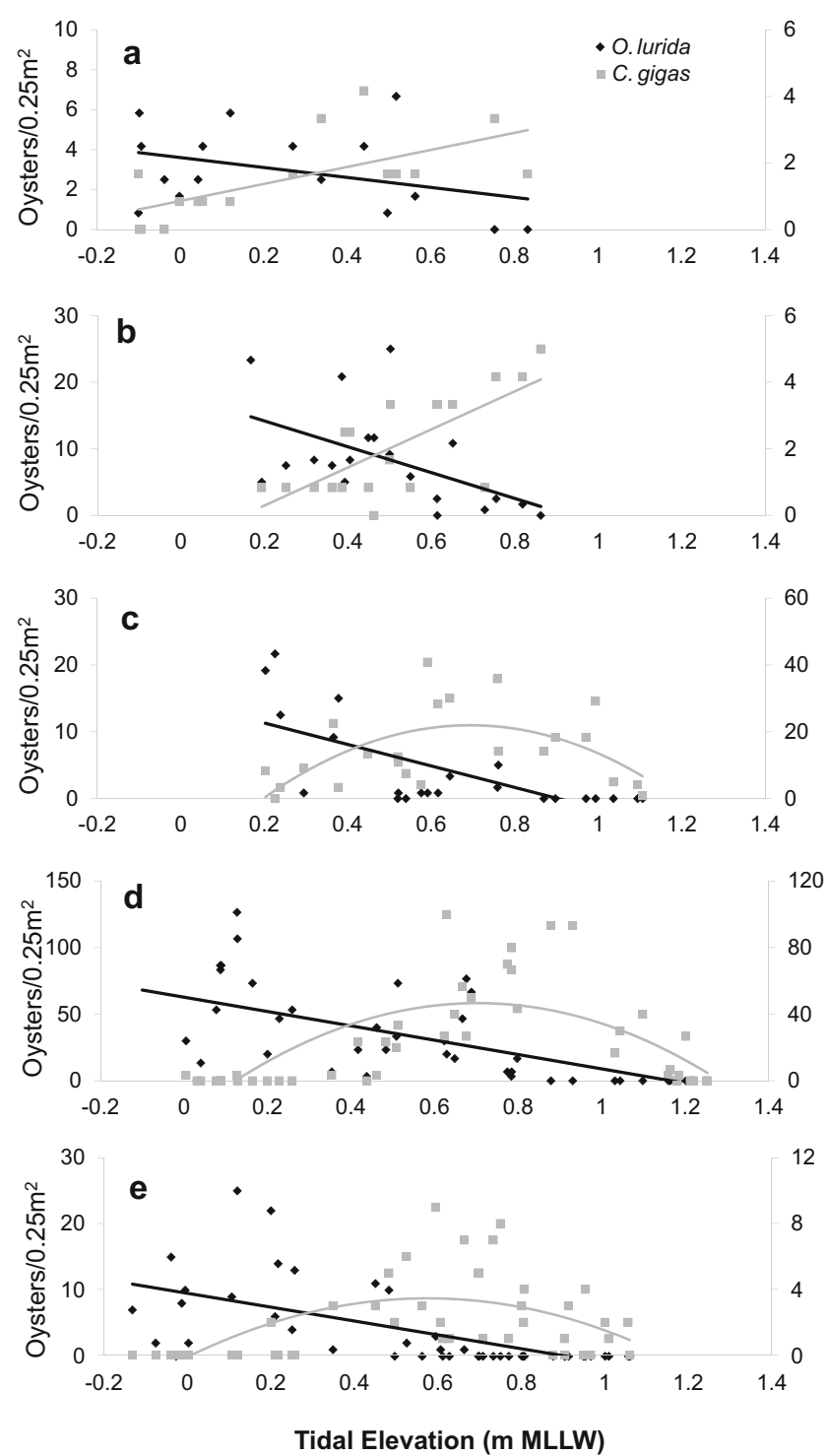

Fig. 5 O. lurida and C. gigas densities per $0.25 \mathrm{~m}^{2}$ (primary axes depict $O$. lurida density, secondary axes depict $C$. gigas density), as a function of tidal elevation. Each data point represents one quadrat. Note differences in axis scales among graphs. a Huntington Harbour in 2013, including linear regression lines for $O$. lurida: $\mathrm{y}=-2.99 \times+4.33, \mathrm{r}^{2}=0.14$, and $C$. gigas: $\mathrm{y}=3.19 \times+1.04, \mathrm{r}^{2}=0.44$ (b) Alamitos Bay in 2013, including linear regression lines for both species; $O$. lurida: $\mathrm{y}=-23.28 \times+21.66$, $\mathrm{r}^{2}=0.28, \mathrm{~F}(1,18)=6.92, P=0.017, C$. gigas: $\mathrm{y}=5.22 \times-0.15, \mathrm{r}^{2}=0.34$, $\mathrm{F}(1,18)=9.22, P=0.0071$ (c) Glorietta Bay in 2014, including linear regression line for O. lurida: $\mathrm{y}=-19.31 \times+17.42, \mathrm{r}^{2}=0.49$, and 2 nd order polynomial regression line for $C$. gigas: $\mathrm{y}=-107.24(\mathrm{x}-0.64)^{2}+$ $11.99 \times+18.34, r^{2}=0.35$ (d) Glorietta Bay in 2017, including linear regression line for $O$. lurida: $\mathrm{y}=-53.80 \times+62.67, \mathrm{r}^{2}=0.44$, and $2 \mathrm{nd}$ order polynomial regression line for C. gigas: $\mathrm{y}=-138.81(\mathrm{x}-0.64)^{2}+$ $17.44 \times+34.83, \mathrm{r}^{2}=0.49$ (e) Chula Vista Wildlife Reserve in 2017, including linear regression line for $O$. lurida: $\mathrm{y}=-10.54 \times+9.40, \mathrm{r}^{2}=$ 0.38 , and 2 nd order polynomial regression line for $C$. gigas: $\mathrm{y}=-$ $10.78(\mathrm{x}-0.54)^{2}+0.71 \times+3.06, \mathrm{r}^{2}=0.33$

tidal range at GB and CV in San Diego Bay; significant 2nd degree polynomial fits best described the relationships for $C$. gigas and tidal elevation (GB 2014: $F(2,20)=5.29, P=$ 
0.0143; GB 2017: $F(2,42)=20.23, P<0.001$, and CV 2017: $F(2,42)=10.36, P=0.0005$, Fig. $5 \mathrm{c}-\mathrm{e})$.

We surveyed the chain-link fence using comparable techniques at Glorietta Bay in both 2014 and 2017. In a post-hoc density comparison using t-tests, we recorded a 6.6 times increase in density of $O$. lurida (Table 2, $p=$ 0.0015 ), and no change in density of $C$. gigas (Table 2, $p=0.2539$ ). Using two different techniques to measure tidal elevation (laser in 2014 versus RTK-GPS in 2017, see methods), the distribution of the two species remained stable (Fig. 5c-d), with O. lurida declining with tidal elevation and not recorded above $+0.8 \mathrm{~m}$ and $C$. gigas achieving its density maximum between +0.6 and +0.8 m MLLW.

\section{Discussion}

We recorded the most comprehensive and among the first quantitative information on the densities and distributions of Ostrea lurida and Crassostrea gigas in southern California across multiple substrata. We discovered a clear zonation pattern based on tidal elevation for both species. Contrary to previous studies on human-introduced substrata, we did not find higher proportions of NIS C. gigas relative to O. lurida on artificial substrata. Our qualitative observations of multiple size classes of both oyster species at most sites surveyed suggest that both species are regularly recruiting in bays throughout southern California. Subsequent follow-up settlement and recruitment surveys in San Diego Bay and ongoing qualitative observations in Newport Bay confirm this inference (R. Torres and D. Zacherl, personal communication, CSU Fullerton, May 2017).

\section{Distribution Across Tidal Range}

Both species exhibited clear patterns of zonation throughout all bays surveyed with $C$. gigas achieving its maximum density above $+0.4 \mathrm{~m}$ MLLW and $O$. lurida at or below $+0.2 \mathrm{~m}$ MLLW. In Huntington Harbour, we recorded a relatively large number of $O$. lurida (eight) in one quadrat at a relatively high tidal elevation $(0.52 \mathrm{~m}$ MLLW), but instances of $O$. lurida at high tidal elevations were rare. Overall, the trend for $O$. lurida at Huntington Harbour follows the zonation pattern as at other sites.

Previous studies have documented the broad tidal distributions of O. lurida (reviewed in Baker 1995) and have documented higher recruitment rates of $O$. lurida at lower tidal elevations compared to higher tidal elevations (White et al. 2009a), however only a handful have addressed zonation between these two species. Ruesink et al. (2006) allude to the existence of the same zonation pattern we observed in WA state and in B.C. More recently, Valdez et al. (2016) examined zonation patterns for both species at 5 tidal elevations (ranging from $-0.6 \mathrm{~m}$ to $+0.6 \mathrm{~m}$ MLLW) at three locations in WA and found that the $C$. gigas generally increased in density with increasing tidal elevation, in agreement with our findings. However, $O$. lurida density relative to tidal elevation in WA was not consistent across sites; it only marginally increased with depth at one of three sites. Our zonation studies were constrained to locations where hard substrata (seawalls, a cobble field, and a chain-link fence) dominated across all tidal elevations. In contrast, Valdez et al. (2016) collected data at sites that contained eelgrass beds at lower tidal elevations and $C$. gigas reefs at mid to upper intertidal locations. The contrast suggests that the zonation pattern for $O$. lurida may only be detectable when hard substrata are available at all tidal elevations surveyed, as we found generally low $O$. lurida density in soft-sediment habitats relative to hard structured habitats. We suggest that available hard substrata interact with tidal elevation to shape $O$. lurida distributions, and the differences between the two studies in hard habitat available at lower tidal elevations explains the disparity in findings. This is an excellent avenue for future distributional studies of the Olympia oyster.

We know little about the mechanism driving the patterns of zonation between the oysters. In Australia, Krassoi et al. (2008) found that a combination of competitive dominance by NIS $C$. gigas and differences in tolerance to abiotic stress between $C$. gigas and native Saccostrea glomerata created zonation between the two species, with $C$. gigas more dominant in lower tidal elevations compared to $S$. glomerata. The latter had a higher tolerance for aerial exposure, likely due to either increased desiccation tolerance or thermal tolerance or both (Nell 2001). The mechanism driving the zonation pattern between $C$. gigas and $O$. lurida could be differential resistance to desiccation stress, given that $C$. gigas is much larger (maximum lengths above $150 \mathrm{~mm}$ versus $O$. lurida, typically $<70 \mathrm{~mm}$ in length), and likely less prone to desiccation. Differences in thermal tolerance could also play a role. When oysters were exposed to elevated water temperatures in experimental studies, the temperature that induced $100 \%$ mortality was lower for adult $O$. lurida $\left(39^{\circ} \mathrm{C}\right.$, Brown et al. 2004) than for adult $C$. gigas $\left(43^{\circ} \mathrm{C}\right.$, Clegg et al. 1998) though their thermal tolerance during aerial exposure is unknown. Other factors that could drive or contribute to the zonation pattern include differential patterns of larval vertical zonation in the plankton and larval settlement across tidal elevations (Grosberg 1982), or competitive interactions (Connell 1961). Importantly, $C$. gigas in southern California is occupying a tidal range similar to that in its native range in Tokyo Bay. In southern California, we generally observed $C$. gigas between +0.2 and +1.2 m MLLW, within and mostly above the mussel (Mytilus galloprovincialis) zone and extending into the upper reaches of the barnacle zone. In Tokyo Bay, Furuse and Furota (1985) documented C. gigas distribution at three sites at tidal elevations ranging between +0.4 and + $1.4 \mathrm{~m}$, again within and above the $M$. galloprovincialis mussel zone and extending into the barnacle zone. 
Regardless of the mechanism, the zonation pattern has important implications due to differences in immersion time between the species. Zu Ermgassen et al. (2013) quantified filtration rates for $O$. lurida, concluding that it may have limited value for improving water clarity, especially relative to Crassostrea species. They note that aqua-cultured C. gigas may play an increasingly important role in restoring the filter feeding ecosystem services previously provided by historic $O$. lurida populations. They list multiple factors to consider when comparing the services provided by different oyster species, including filtration rate, mean size, and mean density. In southern CA, feral $C$. gigas experiences far less immersion than $O$. lurida, and thus experiences less time to perform filtration, necessitating this factor's inclusion in among-species comparisons.

Our data suggest that constructed oyster beds spanning tidal elevations from 0 to +0.3 m MLLW would maximize $O$. lurida density. A zone of overlap exists between the species so any reef occupying tidal elevations between +0.3 and $+0.7 \mathrm{~m}$ MLLW could support both species. Above $\sim+0.7 \mathrm{~m}$ MLLW, $O$. lurida would be excluded. Our observed distributional pattern was consistent across multiple habitat types surveyed including sea walls, a cobble field, and a chain link fence. It is possible that a more complex habitat, such as a constructed oyster bed, may allow one or both species to exploit a broader range of elevations, but finding thus far from three oyster restoration studies in southern California indicate that the distributions of both species on the constructed beds are consistent with those observed in this study (C. Fuentes and D. Zacherl, unpublished data, CSU Fullerton, August 2014).

Another important implication of this zonation pattern involves making comparisons of density among studies across the range of the species. Unless explicitly noted, density measures performed across a broad tidal elevation, or simply characterized as completed "during low tide" may be biased by the actual tidal elevation. For example, on riprap habitat, we recorded exceptionally high $C$. gigas density in San Diego Bay at Grand Caribe (Table 1, Fig. 3). However, the tidal elevation of this survey (ranging from +0.39 to +0.93 m MLLW) was generally higher than any of the other riprap habitat surveyed (4 of 5 other riprap sites surveyed extended down into negative tidal elevations as low as $-0.3 \mathrm{~m}$ MLLW). We cannot discount the possibility that tidal elevation biased our density measures at Grand Caribe; below + 0.4 m MLLW, C. gigas density declines substantially (Fig. 5). Further, zonation patterns likely vary with latitude (Harley and Helmuth 2003; Byers et al. 2015). Thus, among-estuary and among-study comparisons should take into account potential bias due to tidal elevation.

\section{Density and Substratum Availability Surveys}

Our results did not support previous findings of higher proportions of NIS relative to native species on artificial substrata
(Tyrrell and Byers 2007), though it is important to acknowledge that our study only examined one native and one nonindigenous species. If any generalizable pattern exists in our data, it may be that $O$. lurida is proportionally higher than the NIS C. gigas in hard substrate-dominated habitats, whether natural or human-introduced. $O$. lurida actually achieved highest densities on human-introduced habitats (riprap, walls, and pilings) versus natural habitats (soft and cobble) in two of three bays surveyed, though the highest density recorded across all sites was on natural cobble habitat. Our general finding of higher oyster density on human-introduced habitat is in contrast to a recent study on Crassostrea virginica oysters in North Carolina, USA, which found 3 to 8-times higher densities of oysters on natural habitat (oyster reefs) relative to hardened shoreline structures (Theuerkauf et al. 2017) but agrees with findings by Burke (2010) that oysters can achieve higher density on riprap relative to natural habitat. It is unclear if Theuerkauf et al. (2017) took tidal elevation into account and Burke (2010) did not explicitly test for the effects of tidal elevation. Lastly, however, the complete absence of natural oyster beds along most of $O$. lurida's range call to question whether even higher densities of $O$. lurida could be achieved in southern California on natural or restored oyster beds.

Our recorded densities for $O$. lurida were comparable to, or higher than, previous surveys conducted in 2005 and 2006 throughout southern California (Polson and Zacherl 2009). At the one site where we repeated surveys using comparable techniques, Glorietta Bay, we recorded a large increase in O. lurida density from 2014 to 2017. On average, across all habitat types and sites in Newport Bay, we measured $O$. lurida density at 11.99 oysters/ $0.25 \mathrm{~m}^{2}$, double that of the maximum mean density recorded by Polson and Zacherl (2009) in surveys conducted during 2005. O. lurida density was highest in San Diego Bay, and our highest density recorded, at CV (at 54.83 oysters $/ 0.25 \mathrm{~m}^{2}$ ), was approximately 2 -times higher than previously recorded by Polson and Zacherl (2009). Polson and Zacherl (2009) did not report the specific tidal range for their surveyed transects, but rather reported the lowest tide on the days in which surveys were performed, leaving open the question whether data are comparable.

Although $O$. lurida densities were generally higher than those recorded in prior surveys in southern California, they remain low compared to other locations throughout the species' range. In San Francisco Bay, where multiple $O$. lurida restoration efforts have been performed or are underway, Polson and Zacherl (2009) and Wasson et al. (2015) recorded densities ranging from 37 oysters $/ 0.25 \mathrm{~m}^{2}$ to 240 oysters $/ 0.25 \mathrm{~m}^{2}$. In British Columbia, Olympia oyster densities range from 60 to 90 oysters $/ 0.25 \mathrm{~m}^{2}$ at multiple sites (Gillespie 2009; Jacobsen 2009). 
Here, we report the first quantitative data for nonindigenous oysters in southern California. C. gigas densities ranged from $0.13-21.90$ oysters $/ 0.25 \mathrm{~m}^{2}$; at lower densities than $O$. lurida in all but three surveyed sites (SB, YC, and GC; Tables 1 and 2). Interestingly, our surveys at YC and GC were both conducted at a relatively high tidal elevation, indicating the potential tidal elevation sampling bias discussed above. Regardless, this study provides an important baseline against which to compare future $C$. gigas densities. Outside of our study, there are not many published data on feral $C$. gigas density from the U. S. west coast. Notably, C. gigas densities in our study are significantly lower than those recorded recently for feral C. gigas in Puget Sound, WA; Valdez et al. (2016) recorded densities as high as $\sim 88$ oysters $/ 0.25 \mathrm{~m}^{2}$. However, we recorded significant increases in $C$. gigas density over three years at GB (T-test, 2014 vs 2017 surveys, $P=$ 0.0015 , Table 2), indicating that perhaps $C$. gigas populations are growing in southern California. On San Juan Island, WA in the Strait of Juan de Fuca, Klinger et al. (2006) surveyed feral populations of C. gigas and found up to 0.9 oysters $/ 0.25 \mathrm{~m}^{2}$. Other researchers have only qualitatively mentioned the presence of feral $C$. gigas beds in WA and B.C. (e.g., Kelly et al. 2008).

This is the first broad-scale baseline survey of two important oyster species in southern California - one, Ostrea lurida, in the midst of a restoration renaissance, and the other, $C$. gigas, a worldwide invader and potential pest species to this habitat. Our study provides data on densities of both $O$. lurida and $C$. gigas, providing an important benchmark against which future density studies can be compared. We show that characterizing the density or abundance of particular oyster species at any site should take into consideration both habitat type and tidal elevation. Background monitoring of native oysters should continue as restoration interest increases throughout southern California.

Acknowledgements We thank Zacherl and Burnaford lab volunteers for field assistance and Kelly Donovan for creating the site map. Special thanks to Sarah Gilman who played a key role in our early thinking about how to best quantify the zonation pattern and who participated in our earliest surveys. We thank Lindsey Sheehan, P.E., a hydrologist from Environmental Science Associates, for the RTK-GPS surveys. Thanks to anonymous reviewers for improving the quality of this manuscript. These data were part of N. Tronske's (NT) and T. Parker's (TP) senior thesis projects. Funds were provided by California State University (CSU) Missions and Goals Initiative to J.L. Burnaford and D.C. Zacherl (DCZ), by Merkel \& Associates, Inc., California State Coastal Conservancy, CSU Fullerton Senior Intramural Award and Incentive Intramural Research Award to DCZ, by the CSU Fullerton Office of the Provost via Biology Undergraduate Research Scholar Training funds to NT and TP, by National Science Foundation Undergraduate Mentoring in Biology (Division of Biological Infrastructure: 1041203), the CSU Fullerton Rachel Carson Scholarship in Conservation Biology, and the CSU Fullerton Jewel Plummer Cobb Scholarship to NT, and by the CSU Fullerton Department of Biological Science to TP.

\section{Compliance with Ethical Standards}

We have complied with all ethical standards and declare no conflict of interest. All applicable international, national and institutional guidelines for care and use of animals were followed. Oysters collected and sacrificed for identification were permitted via California Department of Fish and Wildlife Scientific Collecting Permits to D. Zacherl and J. Burnaford.

Open Access This article is distributed under the terms of the Creative Commons Attribution 4.0 International License (http:// creativecommons.org/licenses/by/4.0/), which permits unrestricted use, distribution, and reproduction in any medium, provided you give appropriate credit to the original author(s) and the source, provide a link to the Creative Commons license, and indicate if changes were made.

\section{References}

Anderson LWJ (2005) California's reaction to Caulerpa taxifolia: a model for invasive species rapid response. Biological Invasions 7:10031016. https://doi.org/10.1007/s10530-004-3123-z

Baker P (1995) Review of ecology and fishery of the Olympia oyster, Ostrea lurida, with annotated bibliography. Journal of Shellfish Research 14:501-518

Balata D, Piazzi L, Cinelli F (2004) A comparison among assemblages in areas invaded by Caulerpa taxifolia and C. racemosa on a subtidal Mediterranean rocky bottom. Marine Ecology-Pubblicazioni Della Stazione Zoologica Di Napoli I 25:1-13. https://doi.org/10.1111/j. 1439-0485.2004.00013.x

Barrett EM (1963) The California oyster industry vol 123. Resources Agency of California, Department of Fish and Game

Beck MW et al (2011) Oyster reefs at risk and recommendations for conservation, restoration, and management. Bioscience 61:107116. https://doi.org/10.1525/bio.2011.61.2.5

Bonnot P (1935) The California oyster industry. California Department of Fish and Game 21:65-80

Boudouresque CF, Meinesz A, Ribera MA, Ballesteros E (1995) Spread of the green alga Caulerpa taxifolia (Caulerpales, Chlorophyta) in the Mediterranean: possible consequences of a major ecological event. Scientia Marina 59:21-29

Bourne N, Mann R (1979) Pacific oysters, Crassostrea gigas Thunberg, in British Columbia and the South Pacific Islands. In: Exotic species in mariculture. Massachusetts Institute of Technology Press Cambridge, MA and London, England, pp 1-53

Brown HM, Briden A, Stokell T, Griffin FJ, Cherr GN (2004) Thermotolerance and Hsp70 profiles in adult and embryonic California native oysters, Ostreola conchaphila (carpenter, 1857). Journal of Shellfish Research 23:135-141

Buhle ER, Ruesink JL (2009) Impacts of invasive oyster drills on Olympia oyster (Ostrea lurida carpenter 1864) recovery in Willapa Bay, Washington, United States. Journal of Shellfish Research 28:87-96. https://doi.org/10.2983/035.028.0115

Bulleri F, Airoldi L (2005) Artificial marine structures facilitate the spread of a nonindigenous green alga, Codium fragile ssp tomentosoides, in the north Adriatic Sea. Journal of Applied Ecology 42:1063-1072

Bulleri F, Chapman MG (2004) Intertidal assemblages on artificial and natural habitats in marinas on the north-west coast of Italy. Marine Biology 145:381-391. https://doi.org/10.1007/s00227-004-1316-8

Burke RP (2010) Alternative substrates as a native oyster (Crassostrea virginica) reef restoration strategy in Chesapeake Bay. Doctoral Dissertation, College of William and Mary 
Byers JE, Grabowski JH, Piehler MF, Hughes AR, Weiskel HW, Malek JC, Kimbro DL (2015) Geographic variation in intertidal oyster reef properties and the influence of tidal prism. Limnology and Oceanography 60:1051-1063

Carlton JT (1979) Introduced invertebrates of San Francisco Bay. San Francisco Bay: the urbanized estuary:427-444

Clegg JS, Uhlinger KR, Jackson SA, Cherr GN, Rifkin E, Friedman CS (1998) Induced thermotolerance and the heat shock protein-70 family in the Pacific oyster Crassostrea gigas. Molecular Marine Biology and Biotechnology 7:21-30

Cohen AN (2011) The exotics guide: non-native marine species of the North American Pacific Coast. Center for Research on Aquatic Bioinvasions, Richmond, CA, and San Francisco Estuary Institute, Oakland, CA

Cohen AN et al (2005) Rapid assessment survey for exotic organisms in southern California bays and harbors, and abundance in port and non-port areas. Biological Invasions 7:995-1002

Connell JH (1961) The influence of interspecific competition and other factors on the distribution of the barnacle Chthamalus stellatus. Ecology 42:710-723. https://doi.org/10.2307/1933500

Connell SD (2001) Urban structures as marine habitats: an experimental comparison of the composition and abundance of subtidal epibiota among pilings, pontoons and rocky reefs. Marine Environmental Research 52:115-125. https://doi.org/ 10.1016/s0141-1136(00)00266-x

Conte F (1996) California oyster culture. University of California Davis, Department of Animal Science 2:1-7

Cranfield HJ, Michael KP, Doonan IJ (1999) Changes in the distribution of epifaunal reefs and oysters during 130 years of dredging for oysters in Foveaux Strait, southern New Zealand. Aquatic Conservation: Marine and Freshwater Ecosystems 9:461-483. https://doi.org/10.1002/(sici)1099-0755(199909/10)9:5<461::aidaqc353>3.3.co;2-q

Crooks JA, Crooks KR, Crooks AJ (2015) Observations of the non-native Pacific oyster (Crassostrea gigas) in San Diego County, California. Calif Fish Game 101:101-107

Dinnel PA, Peabody B, Peter-Contesse T (2009) Rebuilding Olympia oysters, Ostrea lurida carpenter 1864, in Fidalgo Bay, Washington. Journal of Shellfish Research 28:79-85. https://doi. org/10.2983/035.028.0114

Dumbauld BR, Brooks KM, Posey MH (2001) Response of an estuarine benthic community to application of the pesticide carbaryl and cultivation of Pacific oysters (Crassostrea gigas) in Willapa Bay, Washington. Marine Pollution Bulletin 42:826-844. https://doi. org/10.1016/s0025-326x(00)00230-7

Emmett RLH, Stone SA, Monaco SL, Emmatt MERL, Hinton SA (1991) Distribution and abundance of fishes and invertebrates in west coast estuaries,. Vol II: species life history summaries, ELMR Rep. No. 8. NOANNOS Strategic Environmental Asessments Division, Rockville, MD

Furuse K, Furota T (1985) An ecological study on the distribution of intertidal sessile animals in inner Tokyo Bay. Marine Fouling $5(2): 1-6$

Gillespie GE (2009) Status of the Olympia oyster, Ostrea lurida carpenter 1864, in British Columbia, Canada. Journal of Shellfish Research 28:59-68

Grabowski JH, Hughes R, Kimbro DL, Dolan MA (2005) How habitat setting influences restored oyster reef communities. Ecology 86: 1926-1935

Grizzle RE, Greene JK, Coen LD (2008) Seston removal by natural and constructed intertidal eastern oyster (Crassostrea virginica) reefs: a comparison with previous laboratory studies, and the value of in situ methods. Estuaries and Coasts 31:1208-1220. https://doi.org/10. 1007/s12237-008-9098-8
Grosberg RK (1982) Intertidal zonation of barnacles: the influence of planktonic zonation of larvae on vertical distribution of adults. Ecology 63:894-899. https://doi.org/10.2307/1937228

Guo XM, Ford SE, Zhang FS (1999) Molluscan aquaculture in China. Journal of Shellfish Research 18:19-31

Harley CD, Helmuth BS (2003) Local-and regional-scale effects of wave exposure, thermal stress, and absolute versus effective shore level on patterns of intertidal zonation. Limnology and Oceanography 48: $1498-1508$

Hopkins A (1931) The effects of sulfite waste liquor on the oyster (Ostrea lurida). Bulletin of the Bureau of Fisheries 48:125-160

Hosack GR, Dumbauld BR, Ruesink JL, Armstrong DA (2006) Habitat associations of estuarine species: comparisons of intertidal mudflat, seagrass (Zostera marina), and oyster (Crassostrea gigas) habitats. Estuaries and Coasts 29:1150-1160

Industries NDoP (2012) New South Wales Pacific Oyster Survey 2010. NSW Department of Primary Industries, Port Stephens

Islas-Olivares R (1975) El ostión Japonés (Crassostrea gigas) en Baja California. Ciencias Marinas 2:58-59

Jacobsen R (2009) The living shore: rediscovering a lost world. Bloomsbury Publishing USA

Kelly JR, Proctor H, Volpe JP (2008) Intertidal community structure differs significantly between substrates dominated by native eelgrass (Zostera marina) and adjacent to the introduced oyster Crassostrea gigas (Thunberg) in British Columbia, Canada. Hydrobiologia 596:57-66

Klinger T, Padilla DK, Britton-Simmons K (2006) Two invaders achieve higher densities in reserves. Aquatic conservation: marine and freshwater ecosystems 16:301-311

Krassoi FR, Brown KR, Bishop MJ, Kelaher BP, Summerhayes S (2008) Condition-specific competition allows coexistence of competitively superior exotic oysters with native oysters. Journal of Animal Ecology 77:5-15

Lodge DM et al (2006) Biological invasions: recommendations for US policy and management. Ecological Applications 16:2035-2054. https://doi.org/10.1890/1051-0761(2006)016[2035:birfup]2.0.co;2

Lotze HK, Worm B (2009) Historical baselines for large marine animals. Trends in Ecology \& Evolution 24:254-262

MacKenzie CL Jr, Wakida-Kusunoki AI (1997) The oyster industry of eastern Mexico. Marine Fisheries Review 59:1-13

McGraw KA (2009) The Olympia oyster, Ostrea lurida carpenter 1864 along the west coast of North America. Journal of Shellfish Research 28:5-10

Meyer DL, Townsend EC, Thayer GW (1997) Stabilization and erosion control value of oyster cultch for intertidal marsh. Restor Ecol 5:9399. https://doi.org/10.1046/j.1526-100X.1997.09710.x

Moschella PS et al (2005) Low-crested coastal defence structures as artificial habitats for marine life: using ecological criteria in design. Coastal Engineering 52:1053-1071. https://doi.org/10.1016/j. coastaleng.2005.09.014

Nell JA (2001) The history of oyster farming in Australia. Marine Fisheries Review 63:14-25

Piazza BP, Banks PD, La Peyre MK (2005) The potential for created oyster shell reefs as a sustainable shoreline protection strategy in Louisiana. Restoration Ecology 13:499-506. https://doi.org/10. 1111/j.1526-100X.2005.00062.X

Pister B (2009) Urban marine ecology in southern California: the ability of riprap structures to serve as rocky intertidal habitat. Marine Biology 156:861-873

Polson M, Zacherl DC (2009) Geographic distribution and intertidal population status for the Olympia oyster, Ostrea lurida carpenter 1864, from Alaska to Baja California. Journal of Shellfish Research 28:69-77

Polson MP, Hewson WE, Eernisse DJ, Baker PK, Zacherl DC (2009) You say conchaphila, I say lurida: molecular evidence for restricting the 
Olympia oyster (Ostrea lurida carpenter 1864) to temperate western North America. Journal of Shellfish Research 28:11-21

Raith M (2013) Phylogeny and species diversity of gulf of California oysters (Ostreidae) inferred from mitochondrial DNA. Master thesis, California State University Fullerton

Raith M, Zacherl DC, Pilgrim EM, Eernisse DJ (2015) Phylogeny and species diversity of gulf of California oysters (Ostreidae) inferred from mitochondrial DNA. American Malacological Bulletin 33:263-283

Ruesink JL, Lenihan HS, Trimble AC, Heiman KW, Micheli F, Byers JE, Kay MC (2005) Introduction of non-native oysters: ecosystem effects and restoration implications. Annual Review of Ecological and Evolutionary Systematics 36:643-689. https://doi.org/10.1146/ annurev.ecolsys.36.102003.152638

Ruesink J, Feist BE, Harvey C, Hong J, Trimble A, Wisehart L (2006) Changes in productivity associated with four introduced species: ecosystem transformation of a 'pristine'estuary. Marine Ecology Progress Series 311:203-215

Ruiz GM, Fofonoff PW, Carlton JT, Wonham MJ, Hines AH (2000) Invasion of coastal marine communities in North America: apparent patterns, processes, and biases. Annual Review of Ecological and Evolutionary Systematics 31:481-531. https://doi.org/10.1146/ annurev.ecolsys.31.1.481

Sagarin RD, Barry JP, Gilman SE, Baxter CH (1999) Climate-related change in an intertidal community over short and long time scales. Ecological Monographs 69(4):465-490

Shatkin G, Shumway SE, Hawes R (1997) Consideration regarding the introduction of the Pacific oyster (Crassostrea gigas) to the Gulf of Maine: a review of global experience. Journal of Shellfish Research 16:463-477

Smith D, Stephenson M, Goetzl J, Ichikawa G, Martin M (1987) The use of transplanted juvenile oysters to monitor the toxic effects of tributylin in California waters. In: OCEANS'87, 1987. IEEE, pp 1511-1516

Stephenson M, Smith D, Goetel J, Icnikawa G, Martin M (1986) Growth abnormalities in mussels and oysters from areas with high levels of tributyltin in San Diego Bay. In: OCEANS'86, 1986. IEEE, pp 1246-1251

Theuerkauf SJ, Eggleston DB, Theuerkauf KW, Puckett BJ (2017) Oyster density and demographic rates on natural intertidal reefs and hardened shoreline structures. Journal of Shellfish Research 36:87-100. https://doi.org/10.2983/035.036.0111

Tierra Data, Inc. (2013) San Diego Bay integrated natural resources management plan, September 2013. U.S. Department of the Navy, Naval
Facilities Engineering Command Southwest and Port of San Diego, Escondido, California

Trianni MS (1996) The influence of commercial oyster culture activities on the benthic infauna of Arcata Bay. Master thesis, Humboldt State University Humboldt, CA

Trimble AC, Ruesink JL, Dumbauld BR (2009) Factors preventing the recovery of a historically overexploited shellfish species, Ostrea lurida carpenter 1864. Journal of Shellfish Research 28:97-106. https://doi.org/10.2983/035.028.0116

Troost K (2010) Causes and effects of a highly successful marine invasion: case-study of the introduced Pacific oyster Crassostrea gigas in continental NW European estuaries. Journal of Sea Research 64:145-165

Tyrrell MC, Byers JE (2007) Do artificial substrates favor nonindigenous fouling species over native species? Journal of Experimental Marine Biology and Ecology 342:54-60

Valdez SR, Peabody B, Allen B, Blake B, Ruesink JL (2016) Experimental test of oyster restoration within eelgrass. Aquatic Conservation: Marine and Freshwater Ecosystems

Wasson $\mathrm{K}$ et al (2015) A guide to Olympia oyster restoration and conservation: environmental conditions and sites that support sustainable populations. Elkhorn Slough National Estuarine Research Reserve, JT Litho

White J, Buhle ER, Ruesink JL, Trimble AC (2009a) Evaluation of Olympia oyster (Ostrea lurida carpenter 1864) status and restoration techniques in Puget sound, Washington, United States. Journal of Shellfish Research 28:107-112

White J, Ruesink JL, Trimble AC (2009b) The nearly forgotten oyster: Ostrea lurida carpenter 1864 (Olympia oyster) history and management in Washington state. Aquaculture 28:43-49

Withgott J (2002) Invasive species - California tries to rub out the monster of the lagoon. Science 295:2201-2202. https://doi.org/10.1126/ science.295.5563.2201

Zacherl DC, Moreno A, Crossen S (2015) Exploring restoration methods for the Olympia oyster, Ostrea lurida carpenter, 1864: effects of shell bed thickness and shell deployment methods on shell cover, oyster recruitment, and oyster density. Journal of Shellfish Research 34:819-830. https://doi.org/10. 2983/035.034.0311

Zu Ermgassen P, Gray M, Langdon C, Spalding M, Brumbaugh R (2013) Quantifying the historic contribution of Olympia oysters to filtration in Pacific coast (USA) estuaries and the implications for restoration objectives. Aquatic Ecology 47:149-161 